УДК 327(497.1:436)"1972"

323.285:314.151.3-054.7(=163.42)(497.1)"1972"

DOI https://doi.org/10.31212/tokovi.2018.3.dra.87-106

Оригинални научни рад

Примљен: 29. 8. 2018.

Прихваћен: 16. 11. 2018.

Petar Dragišić

Institute for Recent History of Serbia petar.dragisic@gmail.com

\title{
Operation Phoenix in Yugoslavia in the Summer of 1972 and Yugoslav-Austrian Relations*
}

\begin{abstract}
The paper examines the operation carried out by the Croatian Revolutionary Brotherhood (CRB) in Yugoslavia in the summer of 1972, as well as the consequences of this affair on Yugoslav-Austrian relations. The article focuses on the key aspects of the action of the CRB in Yugoslavia and its impact on relations between Belgrade and Vienna. The work presented in this paper is based on archive sources and Yugoslav press reports.
\end{abstract}

Key words: Austria, Yugoslavia, Croatian migrants, 1972, Croatian Revolutionary Brotherhood

In the late 1960s and 1970s, Yugoslavia was confronted with several insuperable political and economic problems, which revealed the utmost fragility of the Yugoslav socialist system. The debacle of the economic reform, the student rebellion in 1968, the mass migration from Yugoslavia to Western Europe, and, last but not least, the high ethnic tensions, represented a major threat to the Yugoslav "socialist paradise."1 The Serbo-Cro-

\footnotetext{
* This article has been written within the framework of the scholarly project Tradition and Transformation - Historical Heritage and National Identity in Serbia in the 20th Century (№ 47019), financed by the Ministry of Education, Science and Technological Development of the Republic of Serbia

1 On political tensions in Yugoslavia in the 1960s and 1970s, see: Branko Petranović, Istorija Jugoslavije 1918-1988, III, (Beograd: Nolit, 1989); Dejan Jović, Jugoslavija država kojaje odumrla: uspon, kriza i pad ČetvrteJugoslavije:(1974-1990.), (Beograd/
} 
atian language dispute, ${ }^{2}$ the Albanian uprising in Kosovo and Macedonia in $1968,{ }^{3}$ as well as the "Croatian Spring" in the early 1970s, presaged the bloody disintegration of Yugoslavia. Moreover, in the 1960s and 1970s, the Yugoslav system was confronted with extremely violent actions of Yugoslav, particularly Croatian, political migrants. Their bullets and grenades became the key elements of their strategy in fighting against the government in Belgrade. ${ }^{4}$

The most radical group of Croatian migrants was the Croatian Revolutionary Brotherhood (CRB) [Hrvatsko revolucionarno bratstvo HRB]. According to an analysis by the Yugoslav State Secretary for Foreign Affairs from June 1970, the organization was founded in June of 1961 in Australia. The CRB also had branches in Western Europe - in the Federal Republic of Germany, Sweden, France and Spain. As stated in the above mentioned document, the Croatian Revolutionary Brotherhood consisted of "most extreme" young Croatian émigrés, engaged in subversive and terrorist activities. ${ }^{5}$

The document of the Yugoslav Intelligence Service (Služba državne bezbednosti) from June 1972 contains more detailed information on the Croatian Revolutionary Brotherhood. According to this report, the CRB consisted of 200-300 members and a considerable number of activists.

Zagreb: Samizdat B 92, 2003); Branko Petranović, Jugoslovensko iskustvo srpske nacionalne integracije, (Beograd: Službeni list SRJ, 1993); Miodrag Zečević, Početak kraja SFRJ. Stenogram i drugi prateći dokumenti proširene sednice Izvršnog komiteta CK SKJ održane od 14. do 16. marta 1962. godine, (Beograd: Arhiv Jugoslavije, 1998); Slobodanka Kovačević, Putnik Dajić, Hronologija jugoslovenske krize 1942-1993, (Beograd: Institut za evropske studije, 1994); Marko Vrhunec, Šest godina sa Titom (19671973), (Beograd: Društvo za istinu o antifašističkoj narodnooslobodilačkoj borbi u Jugoslaviji (1941-1945), 2000); Sinan Hasani, Kosovo: istine i zablude, (Zagreb: Centar za informacije i publicitet, 1986); Jovan N. Popović, Četvrta sednica CK SKJ - Brionski plenum - (Stenografske beleške sa Četvrtog plenuma, materijali Izvršnog komiteta CK SKJ, Izvod iz stenografskih beležaka Šeste sednice CK SK Srbije, reagovanja domaće i svetske javnosti, pisma, telegrami izjave i dr.), (Beograd, 1999).

2 Слободан Селинић, Србија и језички сукоб у Југославији 1967, (Београд: ИНИС, 2017).

3 Predrag J. Marković, „Služba državne bezbednosti i albanske demonstracije na Kosovu 1968. godine: jedan dokument", Istorija 20. veka 1-2/1999, 169-180.

4 Bojan Dimitrijević, "Istorijski aspekti terorizma u Srbiji", Istorija 20. veka 1/2008, 131-140; Srđan Cvetković, "Terorizam i jugoslovenska politička emigracija”, Istorija 20. veka 2/2014, 171-197.

5 Arhiv Jugoslavije (AJ), fond 142, Socijalistički savez radnog naroda Jugoslavije (SSRNJ), f-474, Državni sekretarijat za inostrane poslove, Savetovanje o problemima vezanim za aktivnost političke emigracije i potrebi stalne i koordinisane protuakcije, 5/6/1979. 
The organization was administered by the revolutionary headquarters (Glavni revolucionarni stan) in Sydney, command posts for continents, regions and towns as well as by the "revolutionary court." In addition, the CRB had several units for special tasks - assassinations, subversions and intelligence. The CRB recruited members among young political migrants and Yugoslav (Croatian) economic emigrants. ${ }^{6}$

The Croatian Revolutionary Brotherhood had various sources of income. The organization was in possession of clubs, hotels, motels, and even football clubs (for example, the Croatia football club, founded in Paris in 1972). In addition, the CRB was financially supported by its members. According to Yugoslav sources, the monthly membership fee (for CRB members in Europe) was 20 Deutsche Marks. ${ }^{7}$

Prior to the well-known Operation Phoenix, the armed groups of the Croatian Revolutionary Brotherhood penetrated Yugoslavia in 1963 and 1967, but failed to achieve their aims, which consequently demoralized the organization. ${ }^{8}$ Nevertheless, the escalation of the so-called Croatian Spring (MASPOK - mass movement) gave fresh impetus to the activities of the Croatian Revolutionary Brotherhood. The ethnic tensions in Yugoslavia in the early 1970s prompted the organization to create additional cells and prepare for a new attack against Yugoslavia. The emergence of the "mass movement" in Croatia mobilized the CRB convincing the organization that the time for action had come. For that purpose, the organization set about creating a center in Austria and cells in Yugoslavia. ${ }^{9}$

6 AJ, fond 803, Predsedništvo SFRJ, f-1867, Savet za poslove državne bezbednosti Materijal za II sednicu Saveta, Savezni sekretarijat za unutrašnje poslove - Služba državne bezbednosti, Informacija o diverzantsko-terorističkoj aktivnosti protiv SFRJ sa težištem na poslednjim događajima, 11/7/1972.

7 Bože Vukušić, Tajni rat UDBE protiv hrvatskoga iseljeništva, (Zagreb: Klub hrvatskih povratnika iz iseljeništva, 2001), 34; Bože Vukušić, Hrvatsko revolucionarno bratstvo rat prije rata, (Zagreb: Klub hrvatskih povratnika iz iseljeništva, 2012).

8 AJ, fond 803, Predsedništvo SFRJ, f-1867, Savet za poslove državne bezbednosti Materijal za II sednicu Saveta, Savezni sekretarijat za unutrašnje poslove - Služba državne bezbednosti, Informacija o diverzantsko-terorističkoj aktivnosti protiv SFRJ sa težištem na poslednjim događajima, 11/7/1972. - The CRB guerrillas, who had infiltrated into Yugoslavia in the summer of 1967, were captured by Yugoslav security forces as soon as they crossed the Italian-Yugoslav border. The group was equipped, among other things, with 10 kilos of plastic explosives, six guns and more than four hundred anti-Yugoslav leaflets. They had planed acts of sabotage on long-distance power lines and the Zagreb-Rijeka railway line, as well as the dissemination of their propaganda material. Vukušić, Tajni rat UDBE, 36.

9 AJ, fond 803, Predsedništvo SFRJ, f-1867, Savet za poslove državne bezbednosti Materijal za II sednicu Saveta, Savezni sekretarijat za unutrašnje poslove - Služba 
The spectacular anti-Yugoslav activities of Croatian émigrés and their most radical organization, the Croatian Revolutionary Brotherhood, were monitored closely, and not only by the Yugoslav Intelligence Agency. The recently declassified papers of the Central Intelligence Agency (CIA) suggest that this intelligence service was also interested in the Croatian emigrant extremists and the CRB. In the National Intelligence Survey on Yugoslavia (of April 1973) the activities of the Croatian Revolutionary Brotherhood were roughly outlined in a chapter on radical Croatian émigrés. According to this document, the CRB had been flying under the radar until 1968, despite the fact that "prior to that time it carried out terrorist attacks against Yugoslavia from secret bases in West Germany." The authors of this intelligence report stressed that the organization focused its efforts on infiltrating "terrorist groups into Yugoslavia" and carrying out "attacks on Yugoslav diplomatic posts." ${ }^{10}$

In a CIA document from May of 1980, on Yugoslav émigrés, the Croatian Revolutionary Brotherhood was portrayed as "one of the most radical and dangerous Croatian extremist groups." According to the CIA, the organization had been founded by two Croatian émigrés in Australia: Geza Pašti and Miroslav Varoš, and had branches in the Federal Republic of Germany, Austria, Spain, France and Sweden. As stated in the CIA document, the Croatian Revolutionary Brotherhood focused on infiltrating "terrorist groups into Yugoslavia" and attacking "Yugoslav diplomatic officials abroad." Although the Central Intelligence Agency underlined its lack of information on the structure of the Croatian Revolutionary Brotherhood, the CIA document contains a list of several prominent members of the CRB: Srećko Rover, Jure Marić, Ivica Šimunović, Franjo Perčić, Dane Šarić, Josip Senić and Franjo Goreta. ${ }^{11}$

The description of the activities of the Croatian Revolutionary Brotherhood in the abovementioned CIA document reveals the standard features of the modus operandi of the CRB in the 1960s and 1970s - infiltration into Yugoslavia and attacks on Yugoslav diplomats abroad: "Since 1963, the Croatian Revolutionary Brotherhood has been responsible for

državne bezbednosti, Informacija o diverzantsko-terorističkoj aktivnosti protiv SFRJ sa težištem na poslednjim događajima, 11/7/1972.

10 Central Intelligence Agency (CIA), General CIA Records, (FOIA) /ESDN (CREST): CIARDP01-00707R000200100033-9, National Intelligence Survey - Yugoslavia, April 1973.

11 Central Intelligence Agency (CIA), General CIA Records, (FOIA) /ESDN (CREST): CIAP85T00875R001100130099-4, Central Intelligence Agency, National Foreign Assessment Center - Yugoslav Emigre Extremists, 29 May 1980. 
at least four armed incursions into Yugoslavia. It seemed to be planning another [infiltration - author's note] before 19 of its members were arrested in 1978 at a guerrilla training camp near Eden, Australia. In addition, the group assassinated two Yugoslav consular officials - one in $\mathrm{Mu}-$ nich in 1966 and another in Frankfurt in 1976 - and wounded another in an assassination attempt in West Germany in 1965. It also planned other assassinations which, for various reasons, had been unsuccessful."12

In the summer of 1972, 19 CRB guerrillas infiltrated into Yugoslavia, thus launching the most spectacular operation in the entire history of the Croatian Revolutionary Brotherhood. According to Yugoslav archive sources, the plan for the covert action of the Croatian Revolutionary Brotherhood in 1972 was drawn up several months earlier. It was decided that the group should penetrate into Yugoslavia from Austria and try to reach its final destination - Bosnia and Herzegovina. The group was advised to avoid attacks on larger Yugoslav garrisons and full-scale confrontations with Yugoslav security forces. Instead, the CRB guerrillas were supposed to throw the Yugoslav security forces into disarray with sudden assaults. The CRB pinned its hopes on a rapid expansion of the infiltrated group by recruiting local Bosnian Croats. Moreover, the CRB had planned two additional operations - poisoning the Belgrade water supply and subversive activity on the Yugoslav-Bulgarian border with the aim of provoking a conflict between Belgrade and Sofia. ${ }^{13}$

Following brief military training in Durlach, near Karlsruhe (Federal Republic of Germany), the terrorists entered Austria in preparation for infiltration into Yugoslavia. After a stopover in Salzburg, the group reached the border area and set up two camps in Styria (Steiermark). On 21 June 1972, the CRB terrorists illegally crossed the Austrian-Yugoslav border and started their major assault against Yugoslavia. ${ }^{14}$

As soon as the CRB commandos penetrated the territory of Yugoslavia, they hijacked a truck in Slovenia and reached the central Yugo-

12 Ibidem.

13 AJ, fond 803, Predsedništvo SFRJ, f-1867, Savet za poslove državne bezbednosti Materijal za II sednicu Saveta, Savezni sekretarijat za unutrašnje poslove - Služba državne bezbednosti, Informacija o diverzantsko-terorističkoj aktivnosti protiv SFRJ sa težištem na poslednjim događajima, 11/7/1972.

14 Ibidem. 
slav federal unit - Bosnia and Herzegovina. Although the Yugoslav intelligence services had obtained basic information on the CRB's Operation Phoenix prior to the infiltration of the Croatian guerrillas, the driver of the hijacked truck provided them with more comprehensive data on the CRB commando task force. On 25 July, the State Security Service of Bosnia and Herzegovina (Služba državne bezbednosti Bosne i Hercegovine) located the infiltrated group in this Yugoslav federal unit. Consequently, the Yugoslav Government promptly prepared a counter-attack. The Yugoslav security forces formed its ad hoc headquarters consisting of both police and Yugoslav People's Army (JNA) units. In addition, the government ordered the mobilization of the Territorial Defense (Teritorijalna odbrana), reserve police forces and military police in the area of Prozor, Bugojno, Kupres, Duvno, and Gornji Vakuf. ${ }^{15}$

The Yugoslav state and party leader, Josip Broz Tito, received the grim news of the CRB operation on 26 July. As stated in the confidential report delivered to Tito, during the exchange of fire with the Yugoslav security forces in the area of Prozor, the Croatian "intruders" had killed a military police commander and wounded two Yugoslav soldiers. In this first confrontation, on 26 June, the Yugoslav forces had only limited success. They managed to liquidate one guerrilla but failed to destroy the rest of the Phoenix group. According to the 26 July report, 300 policemen, 350 soldiers (JNA), 350 members of the reserve police forces as well as 2,000 members of the Territorial Defense participated in the hunt for the Croatian terrorists. The commander in chief of the anti-terrorist operation in Bosnia was Colonel General Nikola Prodanović. He was assisted by high-ranking officials of the State Security Service of Bosnia and Herzegovina and the Federal State Security Service. ${ }^{16}$

In addition to the military aspects, the campaign of the Croatian Revolutionary Brotherhood against Yugoslavia in the summer of 1972 contained noteworthy propaganda facets. During the initial stage of Operation Phoenix, the CRB group distributed leaflets in Bosnia calling for the "revolutionary overthrow" of the Yugoslav regime. The CRB under-

15 Ibidem. - The members of the infiltrated group were: Adolf Andrić, Ambrozije Andrić, Nikola Antonac, Petar Bakula, Filip Bešlić, Vidak Buntić, Vili Eršek, Ilija Glavaš, Đuro Horvat, Viktor Kancijanić, Vejsil Keškić, Vinko Knez, Ilija Lovrić, Ludvig Pavlović, Stipe Ljubas, Vlado Miletić, Ivan Prlić, Pavle Vegar, Mirko Vlasinović. AJ, Predsedništvo SFRJ, f-1867, Savezni sekretarijat za unutrašnje poslove - Služba državne bezbednosti, Podaci za članove ubačene terorističke grupe (II dopunjena verzija), 10/7/1972.

16 AJ, fond 837, Kabinet predsednika Republike (KPR), II-5-d, Informacija o daljoj aktivnosti grupe diverzanata i preduzetim merama, 26/6/1972. 
lined in the leaflets that the "time had come" for the struggle for the survival of the Croatian people and its "holy homeland." The Phoenix group communicated their political and ideological values and goals not only via leaflets. As stated in the abovementioned report, in contacts with local hunters, the insurgents "insolently attacked our [Yugoslav - author's note] social and political system, in particular in the Socialist Republic of Serbia," while stressing that they had nothing against those Croatian communists who fought for "the Croatian cause." Moreover, during their conversation with the hunters in Bosnia, the members of the Phoenix group underlined that Yugoslavia was in a state of anarchy, adding that the goal of their campaign was to "restore order."17

The Phoenix group was de facto destroyed on 26 and 27 June. By 11 July the Yugoslav security forces had liquidated 9 of the infiltrated guerrillas and put the rest of the group on the run. Additionally, the CRB failed to attract new adherents on the ground, which consequently shattered the CRB's dreams of a mass Croatian uprising in Yugoslavia ${ }^{18}{ }^{H} \mathrm{How}-$ ever, in the clashes with the Phoenix group, the Yugoslav security forces suffered heavy losses. By the end of the anti-terrorist operation in Bosnia, in July of 1972, the Phoenix group had killed 13 and wounded $15 \mathrm{Yu}-$ goslav policemen and soldiers. ${ }^{19}$

Ultimately, the operation of the Croatian Revolutionary Brotherhood in Yugoslavia in the summer of 1972 ended in failure. The most radical Croatian exile organization set itself highly ambitious goals. Their attempt to foment a full-scale Croatian uprising in Yugoslavia was a complete fiasco. The four surviving terrorists - Đuro Horvat, Vejsil Keškić, Mirko Vlasnović and Ludvig Pavlović - were eventually captured and sentenced to death by the military court in Sarajevo. However, the Yugoslav Presidency granted amnesty to the youngest of them - Ludvig Pavlović - whose death sentence was commuted to 20 years imprisonment. ${ }^{20}$ Eventually, Pavlović was released from prison on the eve of the disintegration of Yugoslavia, but soon (in October of 1991) lost his life in Western Herzegovina.

\section{Ibidem.}

18 AJ, Predsedništvo SFRJ, f-1867, Savet za poslove državne bezbednosti - Materijal za II sednicu Saveta, Savezni sekretarijat za unutrašnje poslove - Služba državne bezbednosti, Informacija o diverzantsko-terorističkoj aktivnosti protiv SFRJ sa težištem na poslednjim događajima, 11/7/1972.

19 Diplomatski arhiv Ministarstva spoljnih poslova Srbije (DAMSP), Politička arhiva (PA), no. 325254, Yugoslav Aide-mémoire, August 1972.

20 „Saopštenje Vojnog suda u Sarajevu - Izvršena smrtna presuda nad trojicom članova fašističko-terorističke grupe", Politka, 13/4/1973. 
Operation Phoenix did not end with the elimination of the infiltrated guerrillas. The Yugoslav regime was quite confident that the action of the Croatian Revolutionary Brotherhood in Yugoslavia in the summer of 1972 was a segment of a large-scale operation against Yugoslavia, drawn up and launched by the West. At a session of the Organization of the League of Communists in the Yugoslav People's Army (Organizacija Saveza komunista u JNA), held on 14 July 1972, general Nikola Ljubičić, then Yugoslav defense minister, directly blamed certain "reactionary" circles in the West for supporting Yugoslav radical migrants in their struggle against the regime in Yugoslavia. General Ljubičić contended that the activities of the Yugoslav extreme émigrés, including Operation Phoenix, would have been impossible without the approval of certain Western establishments. ${ }^{21}$

Being confident that Operation Phoenix was part of an international (Western) conspiracy against the communist regime in Yugoslavia, the government in Belgrade launched - immediately after the elimination of the Phoenix group - an intensive diplomatic campaign in Australia, Austria, United States, Federal Republic of Germany, Sweden and France. The crucial elements of this diplomatic campaign were protests against what was perceived in Yugoslavia as a very tolerant attitude toward Yugoslav (in particular Croatian) radical political émigrés. ${ }^{22}$ At meetings with their American counterparts, Yugoslav diplomats in Washington called for a ban on "anti-Yugoslav" activities of Yugoslav immigrants in the United States. In September of 1972, two months after the CRB operation in Bosnia, Yugoslav Foreign Minister Mirko Tepavac reiterated this Yugoslav request at a meeting with US Secretary of State William Rogers. ${ }^{23}$ As already mentioned, Vienna was one of the prime targets of the Yugoslav regime's diplomatic campaign following the failed coup of the Croatian Revolutionary Brotherhood in the summer of 1972.

Prior to Operation Phoenix, relations between Austria and Tito's Yugoslavia had had both positive and negative aspects. The close economic cooperation between the two neighbors comprised, above all, an exten-

21 AJ, fond 507, Savez komunista Jugoslavije (507), Opunomoćstvo CKSKJ za organizaciju SK u JNA, XX-k-11/2, Materijal sa sednice Komiteta Konferencije Organizacije Saveza komunista u JNA, održane 14. jula 1972.

22 AJ, KPR, II-9-b (Emigracija), Beleška, 2/8/1972.

23 Dragan Bogetić, Jugoslovensko-američki odnosi u vreme bipolarnog detanta 19721975, (Beograd, 2015), 40-43. 
sive exchange of goods, huge numbers of Austrian tourists in Yugoslavia, as well as tens of thousands of Yugoslav economic migrants in Austria - Gastarbeiter (150,000 in 1972). In addition, the close relations between Yugoslavia and Austria were manifested in frequent meetings between the key political figures of the two countries. In 1972, Austrian Foreign Minister Rudolf Kirchschläger and Austrian President Franz Jonas visited Yugoslavia and in the same year, Yugoslav Prime Minister Džemal Bijedić (predsednik Saveznog izvršnog veća) paid a return visit to Austria. ${ }^{24}$ The normalization between Tito's Yugoslavia and Austria was a direct consequence of the decision of the Yugoslav regime to give up its territorial claims to Carinthia Kärnten (Austrian province with a Slovene minority) in 1949. ${ }^{25}$

However, the climate between Yugoslavia and Austria was negatively affected by Yugoslav discontent with the Austrian treatment of the Slovene ethnic population in Austria. In the early 1970s, Belgrade and Ljubljana strongly criticized the implementation of Article 7 of the Austrian State Treaty (Staatsvertrag), which guaranteed the rights of the Slovene and Croatian minorities in Austria. The Yugoslav regime particularly denounced the abolishing of compulsory bilingual education (German-Slovene) in Carinthia, the revival of the Carinthian far-right organization, the "Heimatdienst" (Carinthian Homeland Service), and the allegedly limited usage of Slovenian language in Carinthia. ${ }^{26}$ Moreover, Belgrade blamed the Austrian authorities for what was viewed in Yugoslavia as tolerance for „hostile actions (in Austria) against Yugoslavia." In this regard, the Yugoslav Government was particularly outraged by the activities of extreme Croatian political migrants in Salzburg, led by the Catholic priest, Vilim Cecelja. ${ }^{27}$

The activities of Croatian radical immigrants in Austria became a bone of contention between Belgrade and Vienna even before the operation

24 AJ, CKSKJ, Komisija za međunarodne odnose i veze, IX, 6/I-287, Odnosi SFR Jugoslavija-Austrija (1972); Petar Dragišić, "Tito i Austrijanci. Susreti Josipa Broza Tita sa vodećim ličnostima austrijske politike 60-ih i 70-ih godina", Tito - viđenja i tumačenja, zbornik radova, ur. Olga Manojlović Pintar, (Beograd, 2011), 498-504.

25 On the Carinthian issue in Austrian-Yugoslav relations, see: Arnold Suppan, „Die Kärntner Frage in den österreichisch-jugoslawischen Beziehungen 1945-1955“, Das gemeinsame Kärnten/Skupna Koroška, (Klagenfurt, 1991); Arnold Suppan, „Jugoslawien und der österreichische Staatsvertrag", Der österreichische Staatsvertrag: Internationale Strategie, rechtliche Relevanz, nationale Identität, Hrsg. Arnold Suppan, Gerald Stourzh, Wolfgang Müller, (Wien, 2005); Petar Dragišić, Odnosi Jugoslavije i Austrije 1945-1955, (Beograd, 2013).

26 AJ, CKSKJ, Komisija za međunarodne odnose i veze, IX, 6/I-287, Neki problemi jugoslovensko-austrijskih odnosa, novembar 1972.

27 Ibidem. 
of the Croatian Revolutionary Brotherhood in Yugoslavia in 1972. During a meeting with Oswald Peterlunger, head of the III section of the Austrian Interior Ministry, Mihael Jurman, the counselor of the Yugoslav embassy in Vienna, fiercely criticized the purported Austrian tolerance of "anti-Yugoslav propaganda activities," i.e. the distribution of newspapers of Yugoslav émigrés in Austria - in Vienna (Südbahnhof, Mexikplatz, in front of the Stephansdom) and Traiskirchen. Moreover, Jurman expressed the hope that Austria would change its position on this contentious issue. ${ }^{28}$

A week later, Yugoslav diplomats in Vienna (Metikoša and Jurman) met with Oswald Peterlunger once again to discuss the problem of "anti-Yugoslav activities" of Yugoslav "fascist" organizations in Austria. Metikoša and Jurman stressed the inadequacy of their police measures against Yugoslav (Croatian) émigrés in Austria. In this regard, the Yugoslav diplomats underlined the pivotal role of Vilim Cecelja in the pro-Ustasha milieu in Austria. In addition, Metikoša and Jurman urged Austrian police to act more decisively against radical Yugoslav immigrants in Austria, i.e. to dissolve their organizations and punish their members adequately. Peterlunger denied the Yugoslav allegations, claiming that the Austrian police had adopted appropriate measures, albeit acting within the law. ${ }^{29}$

The Yugoslav discontent with the Austrian policy toward the extreme Croatian émigrés in Austria grew after the Phoenix affair in the summer of 1972 , given that the CRB group had been partially trained on the territory of Austria and that the group had penetrated Yugoslavia by crossing the Austrian-Yugoslav border. According to Yugoslav sources, the intense activities of the Croatian Revolutionary Brotherhood on Austrian soil were coordinated by prominent Croatian émigrés Đuro Horvat and Ilija Glavaš. Moreover, the apartment of Ilija Glavaš in Salzburg served as the temporary headquarters of the CRB group prior to its terrorist operation in Yugoslavia. ${ }^{30}$

As early as August 1972, the Yugoslav Government lodged a protest with the Austrian Government. The Yugoslav ambassador in Vienna, Mitja Vošnjak, met with Austrian Chancellor Bruno Kreisky and handed

28 DAMSP, PA, 1968, f-74, no. 411696, Ambasada Socijalističke Federativne Republike Jugoslavije u Austriji (Beč), Zabeleška iz razgovora savetnika M. Jurmana sa Sektion Chefom dr. Peterlunger Oswaldom, rukovodiocem III sekcije MUP (državna policija STAPO i civilna zaštita), vođenog dana 29/2/1968.

29 DAMSP, PA, 1968, f-74, no. 411695, Ambasada Socijalističke Federativne Republike Jugoslavije u Austriji (Beč), Zabeleška iz razgovora savetnika M. Metikoša i M. Jurmana sa Sektion Chefom dr. Peterlunger Oswaldom, rukovodiocem III sekcije MUP-a (državna policija - STAPO i civilna zaštita), vođenog dana 8/3/1968.

30 DAMSP, PA, 1968, f-74, no. 325254, Yugoslav Aide-mémoire, August 1972. 
him an aide-mémoire regarding the CRB's operation in Yugoslavia. ${ }^{31}$ In the Yugoslav memo, the Republic of Austria was blamed for not implementing appropriate measures against the guerrillas of the Croatian Revolutionary Brotherhood, who had received military training on the territory of Austria. As the Yugoslav note pointed out, such behavior on the part of Austria had not been in accordance with Austria's neutrality and friendly relations between the two countries. Moreover, the government of the Socialist Federal Republic of Yugoslavia urged Vienna to prevent all other kinds of hostile activities against Yugoslavia, including military training of terrorists on Austrian soil and their infiltration into Yugoslavia. ${ }^{32}$ According to a report by the Yugoslav news agency TANJUG, Kreisky promised that the Austrian Government would scrutinize the Yugoslav memo thoroughly and take "all possible" measures to prevent such incidents. ${ }^{33}$

The first Austrian reaction to the Yugoslav accusations signaled the Austrian Government's intention to calm the anger of Belgrade and examine the whole affair. In a communiqué issued on 22 August, the Austrian Government emphasized its interest in maintaining friendly relations with the Socialist Federal Republic of Yugoslavia and condemned any kind of terrorist activity. However, the Ballhausplatz denied all responsibility for the action of the Croatian Revolutionary Brotherhood in Yugoslavia in 1972. According to the TANJUG report from late August, the Austrian security services were conducting an extensive investigation into the background of the Phoenix affair. However, several independent and pro-government newspapers in Austria denied Vienna's responsibility for the action of the Phoenix group. In fact, the Yugoslav accusations were perceived as "an insult to Austria." Instead, it was stressed that the Croatian

31 „Protest vlade SFRJ Austriji“, Politika, 19/8/1972; DAMSP, PA, 1968, f-74, br. 325254, Yugoslav Aide-mémoire, August 1972. "Ubacivanje terorističke grupe sa teritorije Austrije u Jugoslaviju pokazuje da nadležni austrijski organi nisu zaustavili ovu grupu u njenim pripremama za ovu akciju na austrijskoj državnoj teritoriji, niti su sprečili njeno ubacivanje u SFRJ. Time nadležni austrijski organi nisu izvršili svoju obavezu koja proističe iz pridržavanja statusa neutralnosti Austrije, i naročito, iz deklarisane prijateljske politike prema Jugoslaviji i izgrađenih prijateljskih odnosa između dve zemlje (...) Na osnovu svega iznetog, vlada SFRJ očekuje od vlade Austrije da neodložno preduzme sve mere da se ubuduće spreči korišćenje austrijske državne terotorije za bilo kakve oblike neprijateljskog delovanja protiv Jugoslavije, a pogotovu za terorističku i diverzantsku obuku terorističkih grupa i njihovo ubacivanje sa austrijske teritorije u Jugoslaviju."

32 AJ, KPR, I-5-b, Austrija, Odgovor austrijske vlade na ed-memoar jugoslovenske vlade, 11/1/1973.

33 „Protest vlade SFRJ Austriji“, Politika, 19/8/1972. 
guerrillas had used Austrian territory only as a transit point. ${ }^{34}$ In August of 1972, the Austrian daily Die Presse reported on a secret camp near Schwanberg (in Styria), which had been used by the Phoenix group prior to its action in Yugoslavia in June and July of 1972. The camp was allegedly discovered by local peasants. ${ }^{35}$

In an interview to the Austrian State Television, Austrian Foreign Minister Rudolf Kirchschläger stressed Vienna's determination to prevent terrorist activities in Austria and underlined Austria's aspirations for better relations with Yugoslavia. At the same time, Kirchschläger emphasized that Austrian authorities could not have foreseen the action of the Croatian Revolutionary Brotherhood in Yugoslavia. ${ }^{36}$ The Austrian chancellor responded to the Yugoslav accusations in the same way. In late August, Kreisky declared that the Austrian authorities would examine the Yugoslav memo, stressing the complexity of keeping 150,000 Yugoslav immigrants in Austria under surveillance. Kreisky reiterated that Austria had no interests in undermining a neighboring country. ${ }^{37}$

In August of 1972, the Yugoslav press published several articles on the activities of the Croatian extreme political émigrés in Austria, particularly in Salzburg. In this regard, the Belgrade daily Borba - the official organ of the Socialist Alliance of the Working People of Yugoslavia (SSRNJ) - focused on the activities of the Croatian Catholic Church in Salzburg and local priest Vilim Cecelja. The Borba correspondent described the masses in Cecelja's church in Salzburg as "anti-Yugoslav meetings," which included calls for the renewal of a state in which the Croats and Catholics would "find freedom and heaven on earth." Cecelja himself was portrayed in the Borba daily as "Pavelić's preacher" and his companion during the Second World War. According to the Borba correspondent, the Yugoslav authorities strongly condemned this political role of the catholic clergy in Salzburg, which eventually led to a curbing of this anti-Yugoslav practice. ${ }^{38}$ Only a few days later, the Borba reported once again on the Croatian community in Salzburg, a town, which after 1967 had evolved into one of the major centers of the Croatian political migrants, underlining Yugosla-

34 „Austrija ispituje terorističku aktivnost ustaša - Pozadina celog slučaja biće obelodanjena", Politika, 22/8/1972.

35 „Otkriveno ustaško skrovište u južnoj Austriji“, Politika, 8/8/1972.

36 „Izjava Kirhšlegera bečkoj televiziji - Austrija je veoma zainteresovana za dobrosusedske odnose sa Jugoslavijom", Politika, 24/8/1972.

37 „Austrija će temeljno ispitati jugoslovenski ed-memoar“, Politika, 26/8/1972.

38 „Ko stoji iza terorista“, Borba, 20/8/1972. 
via's expectation that the Austrian authorities would be able to destroy the "nest of vipers" in Salzburg. ${ }^{39}$

When Austrian President Franz Jonas paid a visit to Yugoslavia only two months after the elimination of the Phoenix group, the activities of the Croatian community in Austria were on top of the agenda of the meetings between Jonas and Josip Broz Tito in Belgrade in September of 1972. During his talks with the Yugoslav leader, Jonas denied Austria's responsibility for the action of the Croatian Revolutionary Brotherhood against Yugoslavia. He reiterated that the Croatian guerrillas had used Austria only as a transit point, underlining that Austria was not a stronghold of anti-Yugoslav terrorists. Moreover, the Austrian president emphasized that $\mathrm{Yu}-$ goslavia's stability was in Austria's best interests. ${ }^{40}$

Two days later, Tito and Jonas met for a second round of talks. This time it was the Yugoslav president who made reference to the Phoenix affair and the activities of the Croatian expatriate community in Austria. Speaking about the operation of the Croatian Revolutionary Brotherhood in 1972, Josip Broz refrained from blaming Austria for this serious incident. The Yugoslav president expressed the hope that this issue would not exacerbate relations between the two countries and that Vienna would prevent such actions by radical Croatian émigrés in Austria. Tito also expressed confidence in the capability of the Austrian secret services to prevent such activities by the Croatian community in Austria, specifically referring to the Croatian milieu in Salzburg and to Vilim Cecelja. ${ }^{41}$

During this second conversation with Tito, the Austrian president underlined two facts, which, in his opinion, hampered the effective con-

39 "Salcburško zmijsko gnezdo", Borba, 26/8/1972.

40 AJ, KPR, I-3-a/6-28, Zabeleška sa razgovora predsednika Tita sa predsednikom Republike Austrije Jonasom u Belom Dvoru 13/9/1972. "President Jonas says that the majority of terrorists were only traveling through Austria, and only three or four stayed on for several months. Taking some written material from his briefcase, which, however, he did not let out of his hands, President Jonas claimed that some terrorists had connections with the Yugoslav Consulate. He states that Austria is definitely not a base for terrorism against Yugoslavia and that it does not allow that, not only out of friendship toward Yugoslavia, but also because of the best interests of general European security (...) President Jonas says that no one can be interested in seeing Yugoslavia undergo changes. Austria is very keen on Yugoslavia being stable. He emphasizes that this was the only case of something like that being launched from Austrian territory."

41 AJ, KPR, I-3-a/6-28, Nastavak razgovora predsednika Tita i predsednika Austrije Jonasa 15. septembra 1972. godine u Belom Dvoru. "We do not blame the Austrian Government for what has happened recently, Comrade Tito continued, but we rightly expect it to help us disable the anti-Yugoslav activities of the emigrant community in Austria." 
trol of Yugoslav migrants in Austria - the enormous volume of traffic between the two countries and staff shortages in the Austrian security services. Nevertheless, Jonas assured his Yugoslav counterpart that Austria was determined to do its best to curb terrorism and settle the issue that strained relations between Austria and Yugoslavia. Also, the Austrian president gave Tito some useful advice on dealing with the problem of anti-Yugoslav migrants, implying Yugoslavia's partial responsibility for their radicalization. Jonas suggested to Tito that Yugoslavs should preventatively act abroad to reduce the power of their extreme political migrants and encourage an anti-fascist orientation among the Yugoslav "workers temporarily employed abroad." 42

The Austrian Government officially responded to the Yugoslav memo in January of 1973. Delivering the Austrian diplomatic note to the Yugoslav deputy foreign minister, the Austrian ambassador in Belgrade stressed that following the Phoenix affair Vienna had initiated cooperation between the Yugoslav and Austrian intelligence services with the aim of preventing "terrorist activities." He reiterated Austria's determination not to let such incidents happen again..$^{43}$ However, in the diplomatic note, the Austrian Government denied any responsibility for the operation of the Croatian Revolutionary Brotherhood in Yugoslavia in the summer of 1972, claiming that Vienna had not been able to foresee the Phoenix affair. Nonetheless, in the concluding section of this document, the Austrian Government vaguely signaled its readiness to reconsider its policy toward Yugoslav (Croatian) political migrants in Austria. ${ }^{44}$

In the following months and years, Operation Phoenix had passed into oblivion. In spite of that, relations between Austria and Yugoslavia did not improve significantly. The unresolved dispute over the Slovenian minority in Carinthia, which became a bone of contention between Belgrade and Vienna in the spring of 1945, continued to generate tension between the two countries and hampered a full normalization of Yugoslav-Austrian relations.

42 Ibidem.

43 AJ, KPR, I-5-b (Austrija), Kabinet predsednika Republike, Služba za spoljnopolitička pitanja, Informacija, 11/1/1973.

44 AJ, KPR, I-5-b (Austrija), Odgovor austrijske vlade na ed memoar jugoslovenske vlade. 


\section{Sources and Literature}

\section{Unpublished sources}

- $\quad$ Arhiv Jugoslavije: Kabinet predsednika Republike (837); Centralni komitet Saveza komunista Jugoslavije (507); Predsedništvo SFRJ (803); Socijalistički savez radnog naroda Jugoslavije (142).

- Diplomatski arhiv Ministarstva spoljnih poslova Srbije (DAMSP). Politička arhiva.

\section{Collections of documents}

- Central Intelligence Agency's Freedom of Information Act Electronic Reading Room.

Newspapers

- Politika

- Borba

\section{Literature}

- Bogetić, Dragan. Jugoslovensko-američki odnosi u vreme bipolarnog detanta 1972-1975. Beograd: ISI i zavod za udžbenike, 2015.

- Cvetković, Srđan. „Terorizam i jugoslovenska politička emigracija“. Istorija 20. veka 2/2014, 171-197.

- Dimitrijević, Bojan. „Istorijski aspekti terorizma u Srbiji“. Istorija 20. veka $1 / 2008,131-140$.

- Dragišić, Petar. „Tito i Austrijanci. Susreti Josipa Broza Tita sa vodećim ličnostima austrijske politike 60-ih i 70-ih godina“. Tito - viđenja i tumačenja, zbornik radova, ur. Olga Manojlović Pintar, 498-504. Beograd, 2011.

- $\quad$ Dragišić, Petar. Odnosi Jugoslavije i Austrije 1945-1955. Beograd: INIS, 2013.

- Hasani, Sinan. Kosovo : istine i zablude. Zagreb: Centar za informacije i publicitet, 1986.

- Jović, Dejan.Jugoslavija - država koja je odumrla: uspon, kriza i pad Četvrte Jugoslavije: (1974-1990.) Beograd/Zagreb: Samizdat B 92, 2003.

- $\quad$ Kovačević, Slobodanka, Putnik Dajić. Hronologija jugoslovenske krize 19421993. Beograd: Institut za evropske studije, 1994.

- Marković, Predrag J. „Služba državne bezbednosti i albanske demonstracije na Kosovu 1968. godine: jedan dokument“. Istorija 20. veka 1-2/1999, 169180.

- $\quad$ Petranović, Branko. Istorija Jugoslavije 1918-1988, III. Beograd: Nolit, 1989.

- Petranović, Branko. Jugoslovensko iskustvo srpske nacionalne integracije. Beograd: Službeni list SRJ, 1993.

- Popović, Jovan N. Četvrta sednica CK SKJ - Brionski plenum - (Stenografske beleške sa Četvrtog plenuma, materijali Izvršnog komiteta CK SKJ, Izvod iz 
stenografskih beležaka Šeste sednice CKSKSrbije, reagovanja domaće i svetske javnosti, pisma, telegrami izjave i dr.). Beograd, 1999.

- Селинић, Слободан. Србија и језички сукоб у Југославији 1967. Београд: ИНИС, 2017.

- Suppan, Arnold. „Die Kärntner Frage in den österreichisch-jugoslawischen Beziehungen 1945-1955“. Das gemeinsame Kärnten-Skupna Koroška. Klagenfurt, 1991.

- Suppan, Arnold. „Jugoslawien und der österreichische Staatsvertrag”. Der österreichische Staatsvertrag: Internationale Strategie, rechtliche Relevanz, nationale Identität, hrsg. Arnold Suppan, Gerald Stourzh, Wolfgang Müller. Wien, 2005.

- Vrhunec, Marko. Šest godina sa Titom (1967-1973). Beograd: Društvo za istinu o antifašističkoj narodnooslobodilačkoj borbi u Jugoslaviji (19411945), 2000.

- Vukušić, Bože. Tajni rat UDBE protiv hrvatskoga iseljeništva. Zagreb: Klub hrvatskih povratnika iz iseljeništva, 2001.

- Vukušić, Bože. Hrvatsko revolucionarno bratstvo rat prije rata. Zagreb: Klub hrvatskih povratnika iz iseljeništva, 2012.

- Zečević, Miodrag. Početak kraja SFRJ. Stenogram i drugi prateći dokumenti proširene sednice Izvršnog komiteta CK SKJ održane od 14. do 16. marta 1962. godine. Beograd: Arhiv Jugoslavije, 1998. 


\section{Summary}

In the Nineteen Sixties and Seventies, Socialist Yugoslavia was faced with many challenges. The failure of its economic reform, the 1968 student rebellion, and the strengthening of centrifugal tendencies in Yugoslav society, were all factors that shook the very foundations of Yugoslav society, revealing the serious weaknesses of the Yugoslav federation. The Yugoslav crisis was further exacerbated by the anti-Yugoslav activities of emigrant extremist groups, of which the worst was the Croatian political emigration and its most radical organization, the Croatian Revolutionary Brotherhood (CRB). According to available Yugoslav and foreign sources, this organization started conducting a mini war against Yugoslavia as far back as the 1960s. Its modus operandi included, first of all, attempts to make illegal incursions into Yugoslavia in order to conduct subversive activities and carry out attacks on Yugoslav diplomatic missions abroad.

The incursion of the CRB task force into Yugoslav territory in the summer of 1972 was the most serious and dangerous operation ever launched by any extremist Croatian political emigrant organization against Yugoslavia and its government. The scale of this operation unnerved the Yugoslav Government, which, in the summer of 1972, encountered considerable difficulties in dealing with this group of 19 infiltrated armed Croatian emigrants. The annihilation of this group in Western Bosnia, however, did not mark the end of the Phoenix affair. In the weeks and months that followed, the authorities in Yugoslavia analyzed this operation launched by the Croatian Revolutionary Brotherhood and its background, seeking to find any possible foreign encouragement for the infiltration of the 19 terrorists into Yugoslavia, thus elevating the Phoenix affair to a higher, diplomatic level.

Since the Yugoslav Government suspected that the CRB operation had been backed by certain circles in the West, Belgrade issued a series of diplomatic protests to countries that harbored large communities of Croatian political emigrants. The Yugoslav protests were also sent to Austria, from whose territory the CRB group had penetrated into Yugoslavia. The Yugoslav authorities, in contact with Austrian officials, repeatedly criticized Vienna's attitude toward its extreme Croatian migrant community, demanding Austria's more vigorous measures in disabling the activities of radical anti-Yugoslav emigrants. This topic was also on the agenda of two meetings between Yugoslav President Josip Broz Tito and Austrian President Franz Jonas, conducted in Yugoslavia in September of 1972. 
The CRB operation in Yugoslavia would thus further jeopardize relations between Yugoslavia and Austria, which were already shaken by the dispute between the two countries over the status of the Slovenian minority in Austria. 


\title{
Резиме
}

Петар Драгишић

\section{Операција Феникс у Југославији у лето 1972. године и југословенско-аустријски односи}

\begin{abstract}
Апстракт: У чланку се анализира операција Хрватског револуцинарног братства у Југославији у лето 1972, као и утицај ове афере на југословенско-аустријске односе. Чланак се фокусура на кључне аспекте акције ХРБ-а у Југославији и њене последице на односе између Београда и Беча. Рад је заснован на архивским изворима и југословенским новинским извештајима.
\end{abstract}

Кључне речи: Аустрија, Југославија, хрватска емиграција, 1972, Хрватско револуционарно братство

Шездесетих и седамдесетих година социјалистичка Југославија је била суочена са више изазова. Неуспех привредне реформе, студенска побуна 1968. и јачање центрифугалних тенденција уздрмали су темеље друштва показујући озбиљне слабости југословенске федерације. Кризу је додатно појачавало деловање екстремних емигрантских група против Југославије и њеног режима, при чему је нејекстремније било деловање хрватске политичке емиграције, чија је најрадикалнија организација било Хрватско револуционарно братство (ХРБ). Према доступним југословенским и иностраним изворима, ова организација је још током шездесетих година започела свој мали рат против Југославије. Њен modus operandi укључивао je, пре свега, покушаје илегалних упада у Југославију у циљу спровођења субверзивних акција и нападе на југословенска дипломатска представништва у иностранству.

Упад групе ХРБ-а у Југославију у лето 1972. представљао је до тада најозбиљнију и најопаснију акцију екстремног дела хрватске политичке емиграције против Југославије и њеног режима. Размере ове операције узнемириле су режим, који се у лето те године, уз приличне тешкоће, обрачунао са групом од 19 убачених наоружаних хрватских емиграната. Разбијање ове групе у западној Босни није, међутим, означило и крај афере Феникс. У недељама и месецима који су 
уследили власти су анализирале ову акцију ХРБ-а и њену позадину, при чему се трагало и за евентуалним спољним подстицајима упада деветнаесторице у Југославију. Тако ће афера Феникс бити подигнута на високи дипломатски ниво.

Како је југословенски режим подозревао да иза акције ХРБ стоје одређени кругови на Западу, Београд је упутио серију дипломатских протеста државама у којима су егзистирале јаке заједнице хрватске политичке емиграције. Југословенски протести нису мимоишли ни Аустрију, са чије територије се група ХРБ-а и убацила у Југославију. Југословенске власти су у контактима са аустријским званичницима отуда у више наврата критиковале однос Беча према тамошњој екстремној хрватској емиграцији, тражећи енергичније ангажовање Аустрије на онемогућавању деловања радикалних антијугословенских емиграната. Ова тема се налазила и на дневном реду два састанка југословенског лидера Јосипа Броза Тита са аустријским председником Францом Јонасом, вођена у Југославији септембра 1972. године. Акција ХРБ-а у Југославији тако ће додатно угрозити односе Југославије и Аустрије, који су већ били пољуљани спором две државе око статуса словеначке мањине у Аустрији. 